\title{
Gonadal structure and gametogenesis of Loricaria lentiginosa Isbrücker (Pisces, Teleostei, Siluriformes)
}

\author{
Rodrigo J. Guimarães-Cruz, José E. dos Santos \& Gilmar B. Santos
}

Programa de Pós-graduação em Zoologia de Vertebrados, Pontifícia Universidade Católica de Minas Gerais. Caixa Postal 2686, 30535-610 Belo Horizonte, Minas Gerais, Brasil. E-mail: enemir@pucminas.br

\begin{abstract}
The gonadal structure and gametogenesis of Loricaria lentiginosa Isbrücker, 1979 were studied through anatomical and histological techniques. Forty two males and ten females in maturation/mature stage were captured in the reservoir of Porto Colombia, Paraná river basin, Minas Gerais, using gill nets, from November 2001 to October 2002 (tri-monthly captures). Examination of the testes revealed that they were paired, elongated and not fringed organs. Histologically, the testes presented three distinct regions: cranial espermatogenic; transistion espermatogenic and secretory; and caudal exclusively secretory. Standard histochemical techniques detected neutral glycoproteins from the secretion of the tubules of the caudal region. Espermatogenesis occurred in cysts throughout the whole extension of the wall of the seminiferous tubules, which anastomosis themselves and liberated the spermatozoa into the lumen of the espermatic ducts. The ovaries were paired, saculiformes and, histologically, they presented ovigerous lamellae that contained the cells of ovogenic ancestry. The oocytes were classified into four stages, based on their cytological characteristics and the cell layers that surrounded them. Post-ovulatory follicles and vitelogenic oocytes in the follicular atresia process also were observed.

KEY WORDS. Espermatogenesis, Loricariidae, ovogenesis, testes secretion.
\end{abstract}

\begin{abstract}
RESUMO. Estrutura gonadal e gametogênese de Loricaria lentiginosa Isbrücker (Pisces, Teleostei, Siluriformes). A estrutura gonadal e a gametogênese de Loricaria lentiginosa Isbrücker, 1979 foram estudadas através de técnicas anatômicas e histológicas. Capturaram-se, trimestralmente, no reservatório de Porto Colômbia, bacia do rio Paraná, Minas Gerais, quarenta e dois machos e dez fêmeas nos estádios em maturação/maduro, utilizando-se redes de emalhar, no período de novembro de 2001 a outubro de 2002. Os testículos são órgãos pares, alongados e não franjados. Histologicamente, os testículos apresentam três regiões distintas: cranial espermatogênica, transição espermatogênica e secretora e caudal exclusivamente secretora. Na secreção dos túbulos da região caudal detectaram-se glicoproteínas neutras. A espermatogênese ocorre em cistos em toda a extensão da parede dos túbulos seminíferos, os quais anastomosam-se e liberam os espermatozóides no lume dos ductos espermáticos. Os ovários são órgãos pares, saculiformes e, histologicamente, apresentam lamelas ovulígeras que contém as células da linhagem ovogênica. Os ovócitos foram classificados em quatro estádios, baseando-se em suas características citológicas e nas camadas que os circundam. Folículos pós-ovulatórios e ovócitos vitelogênicos em processo de atresia folicular foram também observados.
\end{abstract}

PALAVRAS CHAVES. Espermatogênese, Loricariidae, ovogênese, secreção testicular.

Gonadal organization and gametogenesis in Neotropical teleosts have been extensively studied. In general, most published work focuses on biometrical, morphological, physiological and/ or biochemical characters, and the distribution of the different cytoplasmic and nuclear inclusions (TYLER \& SUMPTER 1996, GRIER 2000).

LEgENDRE et al. (1996) reports that some Siluriformes species present fringed testes while others do not. In most fish species gonads are paired organs of similar size, which can be partially or totally fused (LE GAC \& LoIR 1999). Some Siluriformes fishes from families Pimelodidae, Loricariidae and Callichthyidae present secretory activity in the caudal portion of the testes, sometimes forming a seminal vesicle (Lorr et al. 1989).

In terms of spermatogonia distribution, the structure of teleosts testes has two types: in the most common, spermatogonia occur all along the seminiferous tubules, while in Atherinomorph fishes they are confined to the distal portion of these structures (GRIER 1981).

According to various authors (Shrivastava 1967, SRIVASTAVA \& SINGH 1994, MaGalHães et al. 2004) fishes can present cystic or semi-cystic spermatogenesis in relation to the phase of release of germ cells in the cysts to the seminiferous tubules lumen. 
Fishes ovaries can be classified as gymnovaries, a primitive condition founded in lungfishes, sturgeons and bowfins or cystovaries, the condition that characterizes most of the teleosts, where the ovary lumen has continuity with the oviduct (Helfman et al. 2000).

Oogonia development in teleosts fishes varies according to the group, and the determination of oogenesis dynamics allows the understanding of maturation and fertilization processes (Wallace \& Selman 1981). Changes in the nucleus, ooplasm and the surrounding layers characterize the oocyte maturation process (BAzzoli \& Rizzo 1990).

Postovulatory follicles are structures formed after oocyte release; they do not have endocrine function, present a wide irregular lumen, and are rapidly reabsorbed in a process involving the apoptosis of follicular cells (DRUMmond et al. 2000). A degenerative process called follicular atresia reabsorbs vitellogenic oocytes not spawned. This process can also occur, but less frequently, in oocytes in other developmental stages (Miranda et al. 1999).

In Brazil, to meet energy demands, the construction of artificial reservoirs by damming river courses is increasing being employed (Tundis 1978). Today, in Alto Paraná river basin, there are around 130 reservoirs, most of them located sequentially along the Rio Grande, having a total of $3,511 \mathrm{Km}^{2}$ of flooded area (SAntos \& Formagio 2000). The Porto Colômbia reservoir (Fig. 1) is located in the middle of the Rio Grande, on the border of Minas Gerais and São Paulo states, between the municipalities of Planura (Minas Gerais) and Guaíra (São Paulo) (PAIVA 1982).

Siluriformes fishes are very diverse, occurring in the tropical region, especially in South America, Africa and Southeast Asia (DE PINNA 1998). The Loricariidae family has over 650 described species, representing one fourth of all Siluriformes species (ReIs \& SCHAEFER 1998). Loricarids live preferentially in lotic environments with rocky bottoms but they can survive in lentic environments with muddy bottoms (ANTONIUTTI et al. 1985). The species Loricaria lentiginosa Isbrücker, 1979 (Figs 2 to 4) is founded in the Alto Paraná river basin (FerRarIS JR. 2003); it has a dorsoventrally compressed body, covered by small bony plates, and can reach $40 \mathrm{~cm}$ in total length. The mouth is located ventrally, with lips covered in filaments, and it feeds from detritus and algae attached to substrates. It is also a species that expresses parental care (CEMIG 2000).

Since there are no studies focusing on reproductive characteristics in L. lentiginosa, the present study aimed to analyze the gonadic structure and the gametogenesis in this species, using anatomical techniques and light microscopy.

\section{MATERIAL AND METHODS}

\section{Fishes}

Fish captures were carried out once every three months in the period between November 2001 and October 2002 in the Porto Colômbia reservoir $\left(20^{\circ} 07^{\prime} 52^{\prime \prime}\right.$ S-20 $01^{\prime} 69^{\prime \prime} \mathrm{S}$ and $48^{\circ} 34^{\prime} 13^{\prime \prime}$ $\left.48^{\circ} 13^{\prime} 40^{\prime \prime} \mathrm{W}\right)$. Forty-two males and ten females, with, respectively,

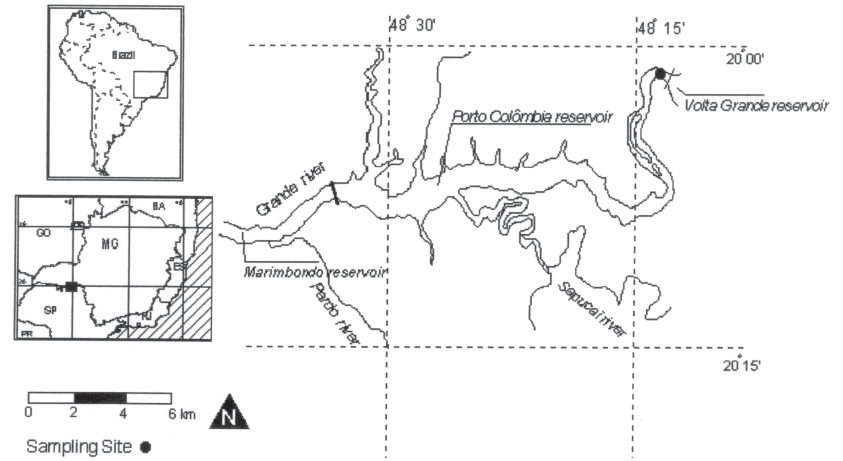

Figure 1. Geographic localization of the Porto Colômbia hydroelectric dam in Minas Gerais.

$21,2-42,5 \mathrm{~cm}$ and $36,5-43,4 \mathrm{~cm}$ of minimum and maximum standard length, in maturation/mature stage were collected using gillnets with mesh sizes between 8 to $20 \mathrm{~cm}$ (stretched measurement). Specimens were fixed in $10 \%$ formaldehyde solution for 24 hours and stored in 70\% ethanol solution, kept in containers and transported to the fish laboratory at Programa de Pósgraduação em Zoologia de Vertebrados da PUC Minas.

\section{Anatomy and light microscopy}

The specimens were dissected and fragments from the cranial and caudal portions of the gonads of all specimens were fixed in Bouin's solution for 6-8 hours. Gonad fragments were embedded in paraffin or in glycol methacrilate, sectioned in serial sections at 3-5 $\mu \mathrm{m}$, and stained with haematoxylin-eosin or with $1 \%$ toluidin blue-sodium borate (JUNQUEIRA \& JUNQUEIRA 1983). The oocytes in L. lentiginosa were classified by histological characteristics into four stages, based on the changes that occurred: in the nucleus, in the ooplasm and in the follicular wall, as proposed by BAzzoli (2003). To detect carbohydrates and proteins on the testes caudal region, the following histochemical techniques were used: PAS (Periodic Acid-Shiff); PAS + amylase; Alcian blue $\mathrm{pH}$ 2,5; Alcian blue $\mathrm{pH}$ 0,5 and ninhydrin-Shiff (PEARSE 1985).

\section{RESULTS}

\section{Testes structure}

The testes of $L$. lentiginosa are paired elongated organs (Fig. 5), dorsally attached to the coelomic cavity by the mesorchium; they were dorsally related to the kidneys and ventrally to the digestive tube. Both testes had spermatic ducts, which join together caudally forming a common spermatic duct that extended to the urogenital papillae.

The testes were surrounded by a tunica albuginea of connective tissue, and they had tubular and interstitial compartments. Morphofunctional organization of the tubular compartment in maturing/mature testes was variable depending on the region: a cranial region ( $86 \%$ total length - tl) with seminiferous tubules containing cysts of spermatogenic lineage cells, in the 


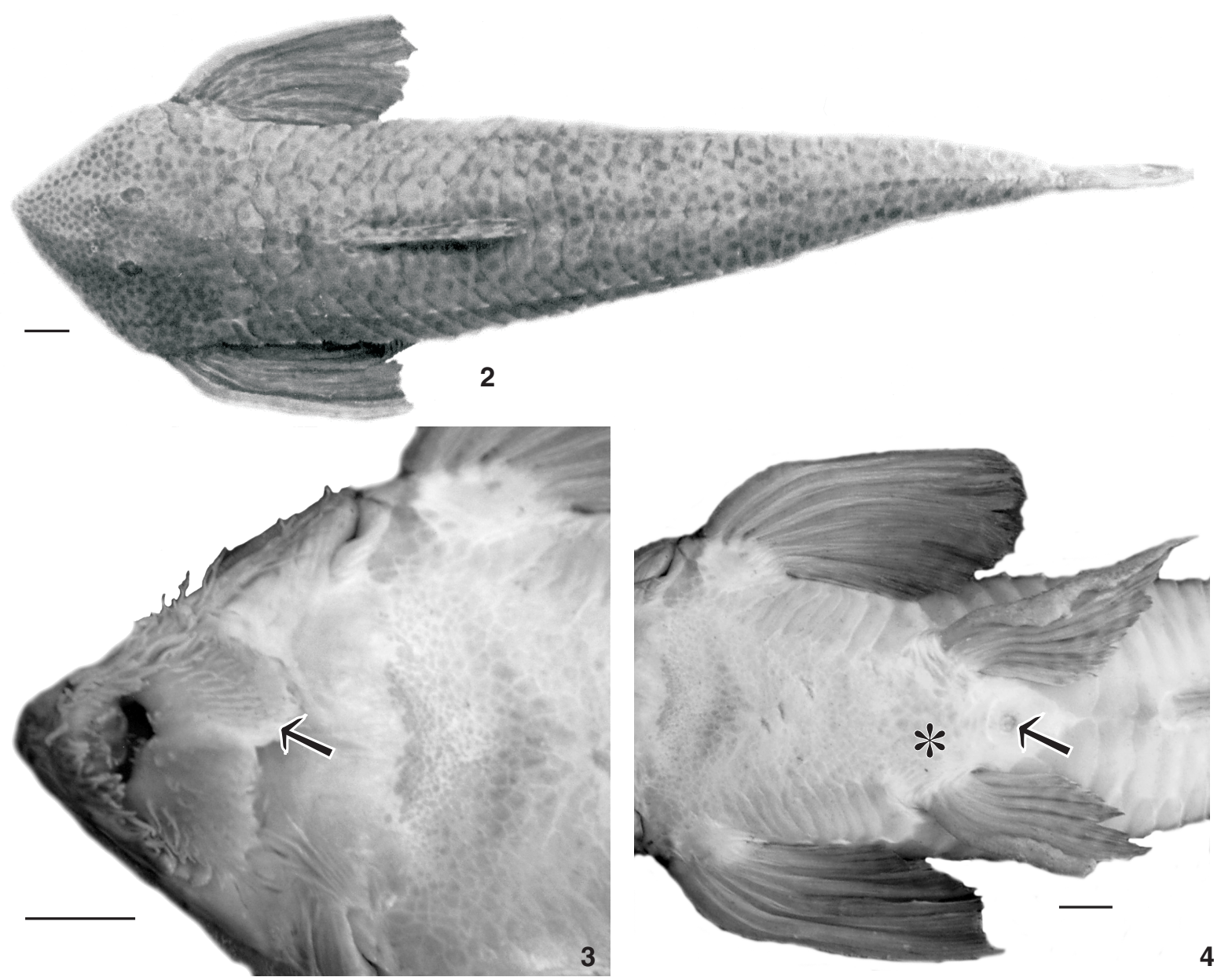

Figures 2-4. (2) L. lentiginosa specimen collected in the Porto Colômbia reservoir, dorsal view; (3) detail of the mouth, showing lips covered with filaments (arrow), ventral view; (4) detail of oocytes impression on body surface (*) and urogenital papillae (arrow), ventral view. Scale bars $=1 \mathrm{~cm}$.

same developmental stage in the walls, and spermatozoa in the lumen (Fig. 6); a transition region (7\% tl), with tubules presenting cysts and secretory prismatic cells in the wall, and spermatozoa and acidophilus secretion in the lumen (Fig. 7); and a caudal region $(7 \% \mathrm{tl})$, where the tubules only exhibited secretory prismatic cells in the wall and acidophilus secretion in the lumen (Fig. 8). Cysts were oval-shaped, delimited by Sertoli cells (insert in Fig. 6A), Leydig cells and conjunctive tissue (insert in Fig. 6B), forming the interstitial tissue. In resting males, the wall of the tubules in the caudal region of the testes has cubic secretory cells with no secretion in the lumen. During spermatozoa release, cysts broke apart releasing the spermatozoa in the tubules lumen (Fig. 9), which anastomosized (Fig. 10) thereby directing the spermatozoa towards the spermatic ducts and then to the common spermatic duct for the spermiation process. In the lumen of the spermatic ducts of maturing/mature testes, acidophilus secretion and spermatozoa were also observed (Fig.
11). The secretion of the testes caudal region reacted positively to the PAS and ninhydrin-Shiff techniques, thereby indicating the presence of neutral glycoproteins.

\section{Spermatogenic cells}

Based on histological characteristics, the following spermatogenic lineage cells were identified:

Primary spermatogonia: the largest of the lineage, occurring only one per cyst, it had abundant cytoplasm, spherical central nucleus with vesicles, and a prominent nucleolus.

Secondary spermatogonia: they formed cysts with two to four cells, having little cytoplasmic material, and a spherical central nucleus with a prominent nucleolus.

Primary spermatocyte: originated from the last generation of secondary spermatogonias after successive mitotic divisions; they had little cytoplasmic content and slightly condensed granulated chromatin in a central nucleus. 

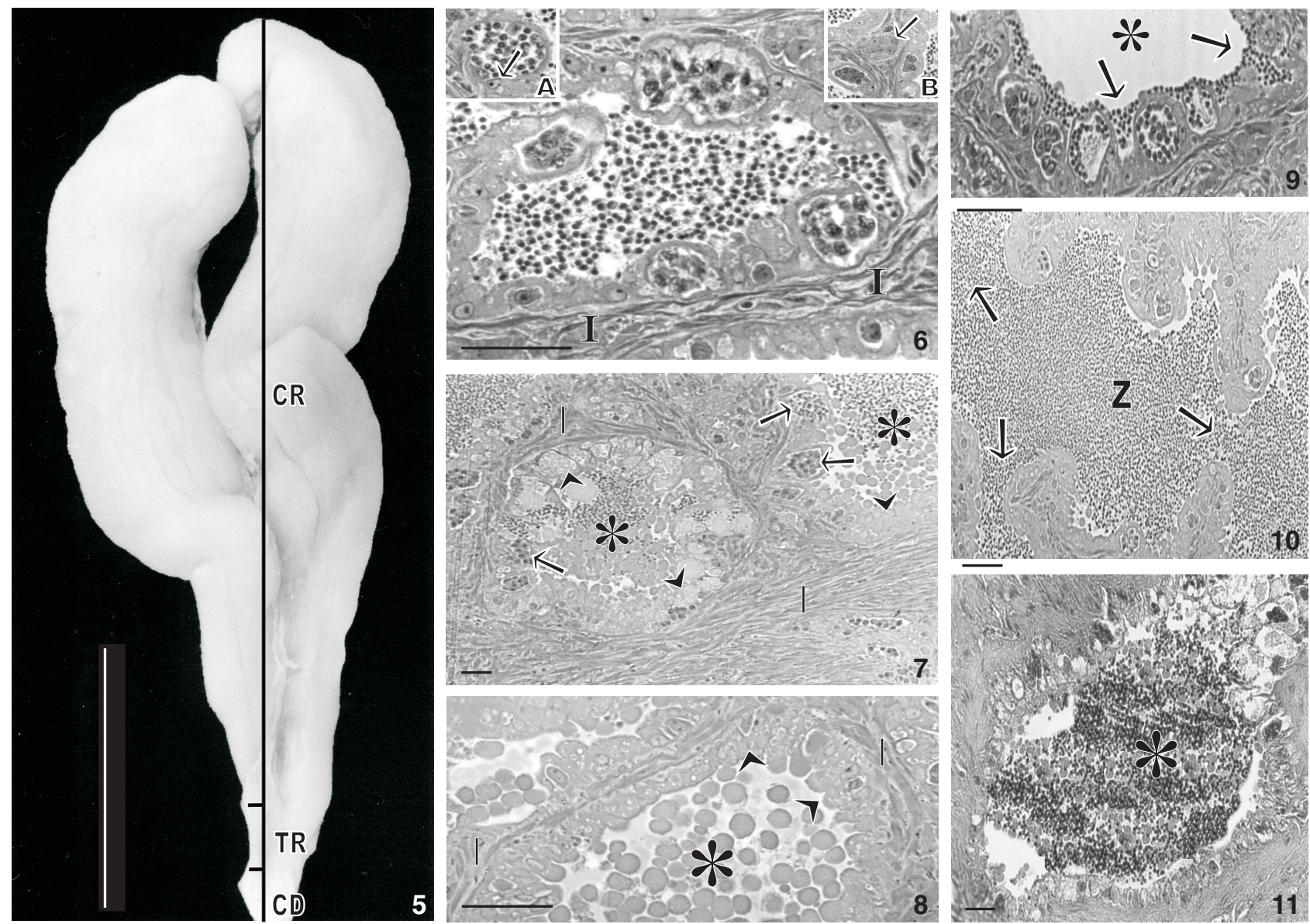

Figures 5-11. Maturing testis and histological transversal section: methacrilate inclusion, stained with $1 \%$ toluidin blue-sodium borate. (5) testis regions: $C R=$ cranial region ( $86 \%$ total length), $T R=$ transition region ( $7 \%$ total length) and $C D=$ caudal region ( $7 \%$ total length); (6) cranial region showing the interstitium $(I)$ and the seminiferous tubule with cysts formed by spermatogenic lineage cells in different developmental stages. In detail: (A) spermatid cyst and Sertoli cell nucleus (arrow), (B) Leydig cells (arrow); (7) transition region showing the interstitium (I), seminiferous tubules with cysts of spermatogenic lineage cells (arrows), secretory prismatic cell (arrow heads) and lumen with spermatozoa and secretion $\left({ }^{*}\right) ;(8)$ caudal region showing the interstitium (I), tubules with prismatic secretory cells (arrow heads) and secretion in the lumen $\left(^{*}\right) ;(9)$ cranial region showing the release of spermatozoa (arrows) into the seminiferous tubule lumen $\left(^{*}\right) ;(10)$ cranial region showing anastomosis of the seminiferous tubules (arrows), full of spermatozoa (Z); (11) caudal portion of the spermatic duct, with spermatozoa and secretion in the lumen $\left(^{*}\right)$. Scale bar: figure $5=1 \mathrm{~cm}$; figures $6-11=100 \mu \mathrm{m}$.

Secondary spermatocyte: originated from the first meiotic division of primary spermatocytes, it had little cytoplasmic content and nucleus with granulated chromatin.

Spermatid: originated from the second meiotic division of secondary spermatocytes, it had little cytoplasmic content and a dense spherical nucleus with a differentiated flagellum.

Spermatozoa: the smallest of the lineage, they had little cytoplasmic content, with no acrosome and a nucleus with heavily condensed chromatin.

\section{Ovaries structure}

Ovaries were saculiform-paired organs (Fig. 12), attached dorsally to the coelomic cavity by the mesovary; they were dorsally related to the kidneys and ventrally to the digestive tube, and joined together caudally to form the ovaric duct that extended to the urogenital papillae. Histological examination of the ovaries showed that they were also coated with the tunica albuginea of conjuntive tissue, which sent septum to the ovaric lumen forming the ovigerous lamellae that contained the oogenic lineage cells.

\section{Oogenisis}

Based on histological characteristics, the following developmental stages of the oogenic lineage cells were identified (Figs 13 to 16):

Revista Brasileira de Zoologia 22 (3): 556-564, setembro 2005 


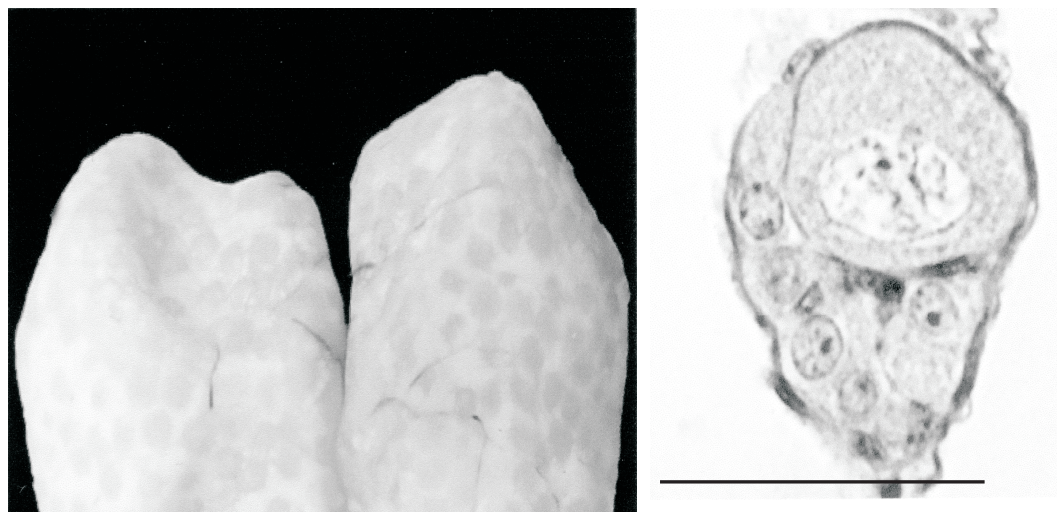

13
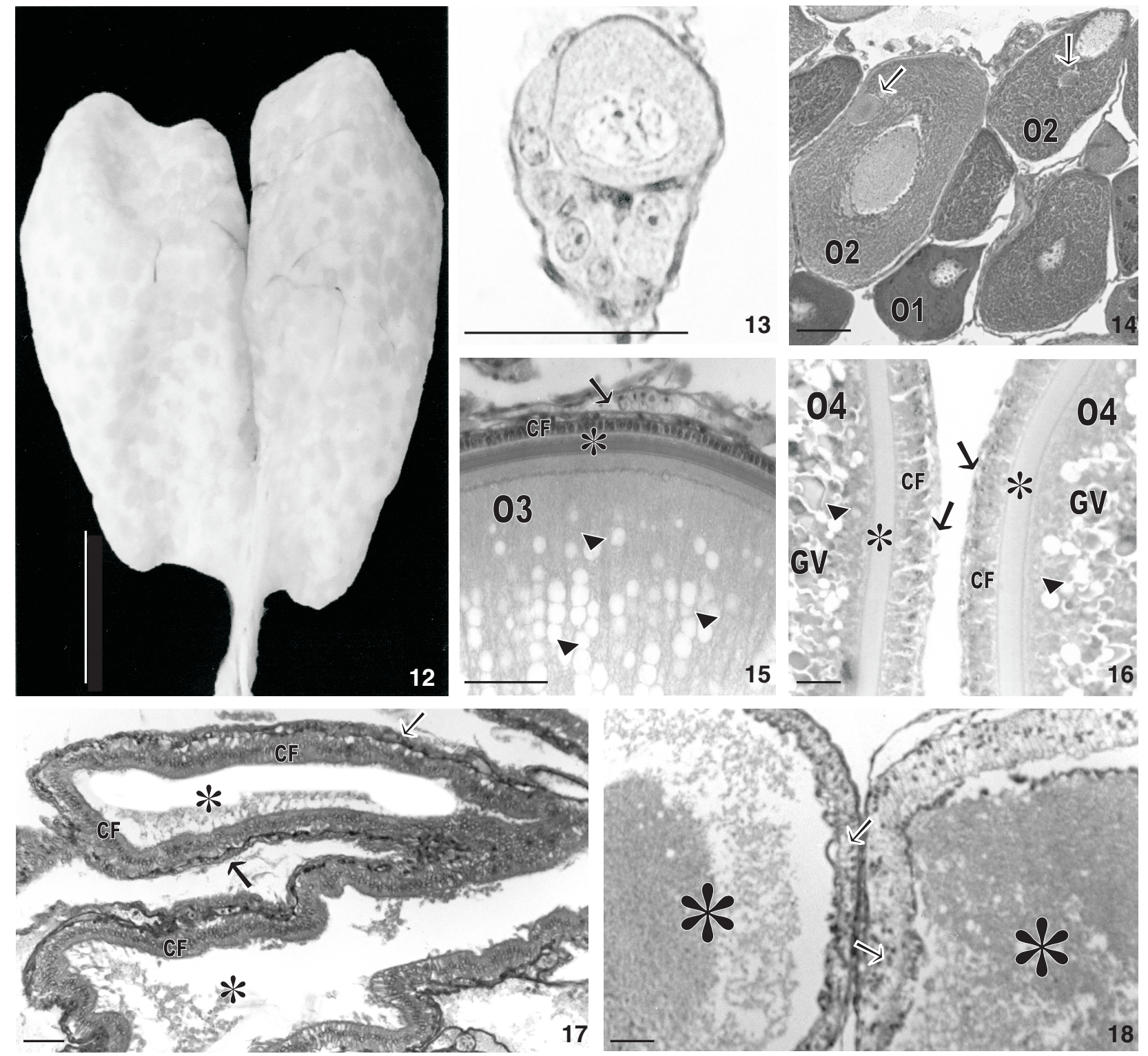

Figures 12-18. Maturing ovaries and histological transversal section: paraffin inclusion stained with haematoxilin/eosin. (12) maturing ovaries; (13) oogonias (arrows) in a nested arrangement; (14) early perinucleolar oocytes (O1) and late perinucleolar oocytes (O2) with vitellogenic nucleus (arrows) in the ooplasma; (15) pre-vitellogenic oocyte (O3) with cortical vesicles (arrow heads) in the ooplasm, zona pellucida $\left({ }^{*}\right)$, cubic follicular cells (CF) and theca with blood vessel (arrow); (16) vitellogenic oocyte (O4) with yolk globules (GV) and cortical vesicles (arrow heads) in the ooplasm, zona pellucida $\left({ }^{*}\right)$, follicular prismatic cells (CF) and theca (arrows); (17) post-ovulatory follicle with wide lumen $\left({ }^{*}\right)$, follicular prismatic cells (CF) and theca (arrows), (18) vitellogenic oocytes in atresia, with liquefaction of yolk globules $\left(^{*}\right)$, zona pellucida fragmentation, and integrity loss of follicular cells and theca. Scale bar: figure $12=1 \mathrm{~cm}$; figures $13-18=100 \mu \mathrm{m}$.

Oogonia: the smallest of the lineage, they were rounded cells found in a nested arrangement; they had little cytoplasmic content, with vesiculous and central nucleus with a unique prominent central nucleolus and the chromatin irregularly located near the nuclear membrane. Oogonias proliferated and produced the oocytes.

Early perinucleolar oocyte: it had a bigger and strongly basophilic cytoplasm with vitreous appearance, a central nucleus and spherical peripheral nucleoli.

Advanced perinucleolar oocyte: it had basophilic granu-

Revista Brasileira de Zoologia 22 (3): 556-564, setembro 2005 
lar ooplasm, central nucleus and spherical nucleoli attached to the nuclear membrane. In the ooplasm of some oocytes it was possible to identify the yolk nucleus, which in the beginning was next to the nucleus and later was displaced to the periphery. The zona pellucida was a thin layer and a unique layer of follicular cells that were pavimentous.

Previtellogenic oocyte: it had cortical vesicles scattered in the ooplasm, which were slightly coloured by haematoxylineosin. The nucleus was central and presented digitiform expansions and a perinuclear halo. The zona pellucida was acellular, acidophilic, and had two layers. Follicular cells were cubic and the theca was thin.

Vitellogenic oocyte: was the largest of the lineage, characterized by the presence of acidophilus yolk globules in the ooplasm. Cortical vesicles were organized in the ooplasm periphery, forming continuous cortical alveoli. The zona pellucida remained with two layers, follicular cells were prismatic, and the theca was similar in thickness to the previous stage and presents capillary blood vessels.

\section{Postovulatory and atretic follicles}

After ovulation, postovulatory follicles were identified; they presented wide irregular lumen and a wall consisting of a unique layer of follicular prismatic cells and the conjunctive theca (Fig. 17). Follicular atresia was observed in vitellogenic oocytes, which presented, through the liquefaction of yolk globules, fragmentation of the zona pellucida and integrity loss of the follicular cells (Fig. 18).

\section{DISCUSSION}

The testes of fresh water Neotropical siluriforms that have external fertilization present variable anatomical characteristics; they are elongated and fringed in the species Pimelodus maculatus La Cepède, 1803 (Bazzoli et al. 1997), Iheringichthys labrosus (Lütken, 1874) (SANTos et al. 2001), Pseudoplatystoma corruscans (Spix \& Agassiz, 1829) (Brito \& BAzzoli 2003) and Conorhynchos conirostris (Valenciennes, 1840) (Lopes et al. 2004); and elongated without fringes in Hypostomus albopucntatus (Regan, 1908) (ANTONIUTTI et al. 1985), Rhinelepis aspera Spix \& Agassiz, 1829 (AgostinHo et al. 1987), Hoplosternum littorale (Hancock, 1828) (Lorr et al. 1989), Liposarcus pardalis (Castelnau, 1855) (Neves \& RuFino 1998) and Loricaria lentiginosa (this study).

In terms of histological appearance, the cranial portion of the testis of $L$. lentiginos $a$ corresponds to the lobular type described by BILLARD (1986) with anastomoses between seminiferous tubules, a characteristic also founded in the testes of $R$. aspera (AgostinHo et al. 1987). The presence of spermatogonia along the whole extension of the seminiferous tubules characterizes the testis of $L$. lentiginosa as unrestricted spermatogonial, under the terminology proposed by GRIER (1981). In this same portion of the testis, the spermatogenic cells were organized in cysts in the walls of the seminiferous tubules, in a manner that all cells in each cyst were in the same developmental stage (PuDNEY 1993). In the cau- dal portion of the maturing / mature testes of L. lentiginosa, secretory tissue was observed, which produced an acidophilus secretion but did not form an individualized glandule. However, LoIR et al. (1989) observed a non-defined seminal vesicle in the caudal region of the testes Hypostomus gymnorhynchus (Norman, 1926); Pseudoancistrus barbatus (Valenciennes, 1840) and Harttia surinamensis (Beseman, 1971) from the family Loricariidae.

Neutral glycoproteins in the secretion of the caudal portion tubules in the maturing / mature testes of L. lentiginosa were also detected in the caudal fringes of I. labrosus; and neutral glycoproteins, carboxylated acid glycoconjugates (including sialomucines and acid and sulfates glycoconjugates) were detected in the caudal fringes of $P$. maculatus (GUIMARÃES-CRUZ $\&$ SANTOS 2004). These substances may have similar functions as those exhibited by substances produced in the seminal vesicles of other teleosts species: acting on female attraction, in the augmentation of the seminal volume and in the fertilization process (VAN DEN HURK et al. 1987, LAHNSTEINER et al. 1992).

Spermatogenesis in teleosts has two different stages: (1) the renewal and proliferation of spermatogonias by mitosis, and (2) meiosis followed by spermiogenesis (Schulz et al. 2000). The disruption of the cystic walls with the release of the germ cells to the lumen of the seminiferous tubules can occur at different developmental stages: secondary spermatocytes (SHRIVASTAVA 1967), spermatids (SRIVASTAVA \& SingH 1994, ANDRADE et al. 2001) and spermatozoa (SANTOS et al. 2001, MAGALHÃEs et al. 2004, present study).

Macroscopic and microscopic appearance of the ovaries of L. lentiginosa were similar to those reported for other species in the family Loricariidae, such as Plecostomus commersonii (Valenciennes, 1840) = Hypostomus scabriceps (Eigenmann \& Eigenmann, 1888) (Agostinho et al. 1982), R. aspera (Agostinho et al. 1987) and Hypostomus punctatus (Menezes \& CARAMASCHI 1994). According to the classification proposed by HOAR (1969), the ovaries of L. lentiginosa would be classified as cystovarian, where the ovarian lumen has continuity with the oviduct, through which the oocytes are released into the environment. In contrast, in some salmon and trout species, the oviduct was lost secondarily, with the oocytes being released to the coelomic cavity and then, to the external environment (Helfman et al. 2000).

Oogenesis consists of the proliferation of oogonia from the germinal epithelium that covers the ovigerous lamellae (GrIER 2000), which divide by mitosis originating oocytes (SELMAN \& Wallace 1989). In the present study, early perinuclear oocytes showed a strongly basophilic cytoplasm, an important characteristic that differentiates them from oogonias, and indicates the beginning of the oogenesis (Ravaglia \& Maggese 2002). Advanced perinuclear oocytes in L. lentiginosa exhibited multiple nucleoli attached to the nuclear membrane, which were constituted by RNA and proteins, that were transferred to the ooplasm to form the vitellogenic nucleus (SELMAN \& W WLLACE 1989), which also has an important role in organelle biogenesis (Guraya 1986). In L. lentiginosa, the yolk nucleus appeared 
as a conspicuous, strongly basophilic structure, that initially was located next to the nucleus and then moved to the periphery where it dispersed as fine granules, as observed by BAzzoLI $\&$ Godinho (1995). The two oocytary stages, early and advanced perinucleolar, of L. lentiginosa relates to the primary oocyte growth described for TYLER \& SUMPTER (1996), characterized by a period of intense RNA synthesis and not gonadotrophic-dependent. In L. lentiginosa previtellogenic oocytes were characterized by the presence of cortical vesicles in the ooplasm, which, according to Micale et al. (1999), release their glycoprotein content in the perivitelline space during fertilization, as a polyspermic inhibiting mechanism. In L. lentiginosa, as in the majority of the teleosts, were the largest cells of this lineage, which presented individualized and spherical yolk granules in the ooplasm. This two stages, previtellogenic and vitellogenic oocytes, of L. lentigosa were related as secondary oocyte growth for TYler \& Sumpter (1996) that is gonadotrophic-dependent.

The formation of an acellular layer, the zona pellucida, during the oogenesis, is described for several teleosts species (GURAYA 1986), and it has multiple functions: it allows the passage of substances to the oocyte interior; protects it from mechanical wear and pathogens; maintains the integrity of the membrane; and promotes the adhesion of the egg to the substrate (Agostinho et al. 1987). In L. lentiginosa, the zona pellucida was observed with a unique acidophilic layer in the late perinucleolar oocytes, and two layers in previtellogenic and vitellogenic oocytes as described for Galeocharax knerii (Steindachner, 1879) by MagalHães et al. (2004).

Follicular cells in L. lentiginosa surround the oocyte forming a unique layer, in a pattern common to all teleosts (SELMAN $\&$ Wallace 1989). These cells can present structural changes during the developmental process of the oocytes (Guraya 1986). In fact, the late perinucleolar oocytes in L. lentiginosa showed pavimentous follicular cells that became cubic in previtellogenic oocytes and prismatic at the end of the vitellogenesis. In the present study it was observed that the theca of previtellogenic and vitellogenic oocytes was constituted of cells that are similar to fibroblasts, presenting capillary blood vessels in the pattern typical of most bony fishes (TyLer \& Sumpter 1996).

Postovulatory follicles in L. lentiginosa had a wide irregular lumen, surrounded by hypertrophied follicular cells and a theca, in a pattern similar to the descriptions made by DRUMMOND et al. (2000) for Astyanax bimaculatus (Linnaeus, 1758).

In teleosts, oocytes not ovulated suffer a degenerative process called follicular atresia (Wallace \& SELman 1981). This process can occur during any phase of the oocyte development (ÜNVER \& ÜnVER SARAYdin 2004); however, its occurrence is unusual during the pre-spawn period (GuRAYA 1986). In the present study, follicular atresia was observed only in vitellogenic oocytes, in ovaries that presented histological characteristics typical of the post-spawned.

As already demonstrated in the present study, the structural organization of $L$. lentiginosa testes presents a cranial sper- matogenic portion, spermatogenic and secretory transition portion, and an exclusively secretive caudal portion with secretory activity only during the maturation period. The spermatogenesis can be classified as cystic, and it occurs along the whole extension of the seminiferous tubules. The ovaries are of the cystovarian type and the oogenesis was characterized histologically by four developmental stages.

\section{ACKNOWLEDGEMENTS}

We wish to thank: PROBIC - PUC Minas for financial support (project $N^{\circ}$ 2003/13); the biologists Dirceu Marzulo and Paulo S. Formagio from the "Estação de Hidrobiologia e Piscicultura de Furnas Centrais Elétricas S/A" for their technical assistance; the biologist Jefferson Lopes for help in the capture of biological material; to Dr Robert J. Young for the suggestions on the english version and the laboratory technicians Rubens Miranda and Rogério da Silva Matos for preparation of the histological plates.

\section{REFERENCES}

Agostinho, A.A.; M.Y. Narahara \& H.M. Godinho. 1982. Morfologia dos ovários de Plecostomus commersonii (Valenciennes, 1840) Osteichthyes-Loricariidae: desenvolvimento dos ovócitos e escala de maturidade. Revista Brasileira de Biologia, Rio de Janeiro, 42 (1): 71-77.

Agostinho, A.A.; M.C. Barbieri; G. Barbieri \& C.S. Agostinho. 1987. Biologia reprodutiva de Rhinelepis aspera (Agassiz, 1829) (Teleostei, Loricariidae) no rio Paranapanema. II. Estrutura dos ovários e estádios de maturação. Revista Brasileira de Biologia, Rio de Janeiro, 47 (3): 319-328.

Andrade, R.F.; N. Bazzoli; E. Rizzo \& Y. Sato. 2001. Continuous gametogenesis in the neotropical freshwater teleost, Bryconops affinis (Pisces: Characidae). Tissue \& Cell, Essex, 33 (5): 524-532.

Antoniutti, K.M.; M.J.T. Ranzani-Paiva; H.M. Godinho \& P. Paiva. 1985. Peso total/comprimento total, crescimento e idade do cascudo Plecostomus albopunctatus Regan, 1908 (Osteichthyes, Loricariidae) do Rio Jaguari, São Paulo, Brasil. Boletim do Instituto de Pesca, São Paulo, 12: 105-120.

Bazzoli, N. 2003. Parâmetros reprodutivos de peixes de interesse comercial do rio São Francisco, região de Pirapora MG, p. 291-306. In: H.P. GodinHo \& A.L. Godinho (Orgs). Águas, peixes e pescadores do São Francisco das Minas Gerais. Belo Horizonte, PUC Minas, 468p.

Bazzoli, N. \& E. Rizzo. 1990. A comparative cytological and cytochemical study of the oogenesis in ten brazilian teleost fish species. European Archives of Biology, Liege, 101: 399410.

Bazzoli, N. \& H.P. GodinHo. 1995. Comparative morphology of the yolk nucleus (Balbiani body) in freshwater neotropical teleost fish. Revista Brasileira de Biologia, Rio de Janeiro, 55 (2): 207-214. 
Bazzoli, N.; L.C.V. Cangussu; E. Rizzo \& G.B. Santos. 1997. Reprodução e desova de mandis Pimelodus maculatus e Iheringichthys labrosus (Pisces, Pimelodidae) nos reservatórios de Furnas, Marimbondo e Itumbiara. Bios. Belo Horizonte, 5 (5): 7-15.

BilLARD, R. 1986. Spermatogenesis and spermatology of some teleost fish species. Reproduction Nutrition Development, Paris, 26: 877-920.

Brito, M.F.G. \& N. BAzzoli. 2003. Reproduction of the surubim catfish (Pisces, Pimelodidae) in the São Francisco River, Pirapora Region, Minas Gerais, Brazil. Arquivo Brasileiro de Medicina Veterinária e Zootecnia, Belo Horizonte, 55 (5): 624-633.

Cemig. 2000. Guia ilustrado de peixes da bacia do rio Grande, p. 32-33. In: M.M. VAz; V.C. TORQuato \& N.D.C. BARbosa (Eds). Belo Horizonte, CETEC, 141p.

DE PINNA, M.C.C. 1998. Phylogenetic Relationships of Neotropical Siluriformes (Teleostei: Ostariophysi): Historical Overview and Synthesis of Hypotheses, p. 279-330. In: L.R. MaLABARBA; R.E. Reis; R.P. VARI; Z.M.S. LuCENA \& C.A.S. LuCENA (Orgs). Phylogeny and Classification of Neotropical Fishes. Porto Alegre, EDIPUCRS, III+603p.

Drummond, C.D.; N. Bazzoli; E. Rizzo \& Y. SAto. 2000. Postovulatory follicle: a model for experimental studies of programmed cell death or apoptosis in teleosts. The Journal of Experimental Zoology, Wiley-Liss, 287: 176-182.

Ferraris JR., C.J. 2003. Subfamily Loricariinae, p. 330-350. In: R.E. Reis; S.O. Kullander; C.J. Ferraris Jr. (Orgs). Check list of the freshwater fishes of South and Central America. Porto Alegre, Editora EDIPUCRS, 729p.

Grier, H.J. 1981. Cellular organization of the testes and spermatogenesis in fishes. American Zoologist, Thousand Oaks, 21: 345-357.

Grier, H.J. 2000. Ovarian germinal epithelium and folliculogenesis in the common snook, Centropomus undecimalis (Teleostei: Centropomidae). Journal of Morphology, New York, 243: $265-281$.

Guimarães-CruZ, R.J. \& J.E. SANTOS. 2004. Testicular structure of three species of neotropical freshwater pimelodids (Pisces, Pimelodidae). Revista Brasileira de Zoologia, Curitiba, 21 (2): 267-271.

GuRAYA, S.S. 1986. The cell and molecular biology of fish oogenesis. Monographs in Developmental Biology, Karger, 18: 1-229.

Helfman, G.S.; B.B. Collette \& D.E. Facey. 2000. The diversity of fishes. Massachusetts, Blachwell Science Editorial, I+528p.

HOAR, W.S. 1969. Reproduction, p. 1-72. In: W.S. HOAR \& D.J. Randall (Eds). Fish Physiology. London, Academic Press, vol. 3, 485p.

JunQueIra, L.C.U. \& L.M.M.S. JunQUeIRA. 1983. Técnicas básicas de citologia e histologia. São Paulo, Livraria Santos Editora, I+121p.

Lahnsteiner, F.; M. Seiwal; R.A. Patzner \& E.A. Ferrero. 1992. The seminal vesicles of the male grass goby, Zosterisessor ophiocephalus (Teleostei, Gobiidae). Zoomorphology, Berlin, 111: 239-248.

LE GAC, F. \& M. LoIR. 1999. Male reproductive system fish, p. 2030. In: E. KNobil \& J.D. NeILl (Eds). Encyclopedia of Reproduction. San Diego, Academic Press, vol. 3, 1072p.

Legendre, M.; O. Linhart \& R. Billard. 1996. Spawning and management of gametes, fertilized eggs and embryos in Siluroidei. Aquatic Living Resources, Montrouge, 9: 59-80.

Loir, M.; C. Cauty; P. Planquette \& P.Y. Bail. 1989. Comparative study of the male reproductive tract in seven families of South-American catfishes. Aquatic Living Resources, Montrouge, 2: 45-56.

Lopes, D.C.J.R.; N. Bazzoli; M.F.G. BRito \& T.A. Maria. 2004. Male reproductive system in the South American catfish Conorhynchus conirostris. Journal of Fish Biology, London, 64: 1419-1424.

Magalhães, A.L.B.; N. Bazzoli; G.B. SAntos \& E. Rizzo. 2004. Reproduction of the South American dogfish characid, Galeocharax knerii, in two reservoirs from upper Paraná River basin, Brazil. Environmental Biology of Fishes, Dordrecht, 70: 415-425.

Menezes, M.S. \& E.P. Caramaschi. 1994. Características reprodutivas de Hypostomus grupo H. punctatus no rio Ubatiba, Marica, RJ (Osteichthyes, Siluriformes). Revista Brasileira de Biologia, Rio de Janeiro, 54 (3): 503-513.

Micale, V.; G. Marichiolo \& L. Genovese. 1999. The reproductive biology of the amberjack, Seriola dumerilli (Risso, 1810). I. Oocyte development in captivity. Aquaculture Research, Oxford, 30: 349-355.

Miranda, A.C.L.; N. Bazzoli; E. Rizzo \& Y. Sato. 1999. Ovarian follicular atresia in two teleost species: a histological and ultrastructural study. Tissue and Cell, Essex, 31 (5): 480-488.

Neves, A.M.B. \& M.L. Rufino. 1998. Aspectos reprodutivos do acari-bodó, Liposarcus pardalis (Pisces, Siluriformes, Loricariidae) (Castelnau, 1855) do médio Amazonas. Boletim do Museu Paraense Emílio Goeldi, Série Zoologia, Belém, 14 (1): 77-94.

PAIVA, M.P. 1982. Grandes represas do Brasil. Brasília, Editerra, $304 p$.

Pearse, A.G.E. 1985. Histochemistry: theoretical and applied. Edinburgh, Churchill Livingstone, II+1055p.

Pudney, J. 1993. Comparative cytology of the non-mammalian vertebrate Sertoli cell, p. 611-657. In: L.D. Russel \& M.D. Griswold (Eds). The Sertoli Cell. Clearwater, Cache River Press, 801p.

Ravaglia, M.A. \& M.C. Maggese. 2002. Oogenesis in the swamp eel Synbranchus marmoratus (Bloch, 1975) (Teleostei; Synbranchidae). Ovarian anatomy, stages of oocyte development and micropyle structure. Biocell, Mendoza, 26 (3): 325-337.

ReIs, R.E. \& S.A. Schaefer. 1998. New cascudinhos from southern Brazil: systematics, endemism, and relationships (Siluriformes, Loricariidae, Hypoptopomatinae). American 
Museum Novitates, New York, 3254: 1-25.

Santos, G.B. \& P.S. Formagio. 2000. Estrutura da ictiofauna dos reservatórios do rio Grande, com ênfase no estabelecimento de peixes piscívoros exóticos. Informe Agropecuário, Belo Horizonte, 21: 98-106.

Santos, J.E.; N. Bazzoli; E. Rizzo \& G.B. SAntos. 2001. Morphofunctional organization of the male reproductive system of the catfish Iheringichthys labrosus (Lütken, 1874) (Siluriformes, Pimelodidae). Tissue and Cell, Essex, 33 (5): 533-540.

Schulz, R.W.; J. Bogerd \& H.J.Th. Goos. 2000. Spermatogenesis and its endocrine regulation. In: Proceedings of the Internacional Symposium on the Reproductive Physiology of Fish, Bergen, vol 6, p. 225-232.

Selman, K. \& R.A. Wallace. 1989. Cellular aspects of oocyte growth in teleosts. Zoological Science, London, 6: 211-231.

SHRIVASTAVA, S.S. 1967. Histomorphology and seasonal cycle of the spermary and sperm duct in a teleost Notopterus notopterus (Pallas). Acta Anatomica, Basel, 66: 133-160.

SRIVASTAVA, S.J. \& R. Singh. 1994. Seasonal changes in the testis of a freshwater murrel, Channa punctatus (Bloch). Naturalia, Paris, 19: 119-130.

Tundisı, J.G. 1978. Construção de reservatórios e previsão de impactos ambientais no baixo Tietê: problemas limnológicos. Biogeografia, São Paulo, 13: 1-19.

TyLer, C.R. \& J.P. Sumpter. 1996. Oocyte growth and development in teleosts. Reviews in Fish Biology and Fishereis, London, 6: 287-318

ÜNVER, B. \& S. ÜNVEr SARaydin. 2004. Histological examination of ovarium development of shemaya Chalcalburnus chalcoides living in Lake Tödürge (Sivas/Turkey). Folia Zoologica, Prague, 51 (1): 99-106.

van den Hurk, R.; J.W. Resink \& J. Peute. 1987. The seminal vesicle of the African catfish, Clarias gariepinus: histological, histoquimical, enzyme-histochemical, ultrastructural. Cell and Tissue Research, New York, 247: 573-582.

Wallace, R.A. \& K. Selman. 1981. Cellular and dynamic aspects of oocyte growth in teleosts. American Zoologist, Thousand Oaks, 21: 325-343.

Received in 24.VIII.2004; accepted in 26.VI.2005. 